episode. Cells were also incubated with dapsone, owing to its similar effect upon erythrocytes, again with inconclusive results.

\section{Discussion}

The administration of diazoxide to this patient has resulted in haemolysis on three occasions. On the first two of these, the fall in haemoglobin was of the order of 5-6 g over a time interval of about 6 weeks, and on the third $3.8 \mathrm{~g}$ in 2 weeks. In episode 2 the diazoxide was continued, and the haemoglobin was maintained at about $10 \mathrm{~g}$ in spite of this. Recovery followed the cessation of treatment and on a reduced maintenance dose, the blood picture has been satisfactory, showing only an occasional fragmented cell.

\section{Mode of action}

Diazoxide is similar in structure to chlorothiazide and to dapsone. The latter is well recognized as an oxidant haemolytic drug which will produce a compensated haemolytic state in normal people, probably owing to stress of the ageing red cell population, possibly mediated through the sulphone groups.

The oxidant agent may interfere with the membrane, or with glycolysis, leading to swelling and leakage with subsequent spherocytosis and fragmentation of the erythrocyte (Dacie, 1967).
The diazoxide was discontinued in the first episode, on account of the fall in haemoglobin, but it appears probable that a compensated haemolytic state would have been reached as, to some extent, occurred in episode 2. Diazoxide has a relatively long half-life, and is excreted in the urine. It is therefore probable that high levels of the drug may be reached in the plasma, particularly if there is any degree of renal failure.

Neutropenia and thrombocytopenia have been reported as a result of diazoxide therapy, but haemolysis has not previously been noted (Combs, Grunt and Brandt, 1967; Wales and Wolff, 1967). However, the latter authors report such a case in which a haemoglobin fall of $3.3 \mathrm{~g}$ occurred over 8 days and haemolysis would appear to be the likely explanation in this instance.

\section{References}

Combs, J.T., Grunt, J.A. \& BrandT, I.K. (1967) Hematological reactions to diazoxide. Pediatrics, 40, 90.

Davie, J.V. (1967) The Haemolytic Anaemias, 2nd edn, p. 1040. Churchill, London.

Symchowicz, S., Black, W.J., Smith, M., Calesnick, B. \& TABACHNICK, I.I.A. (1967) Diazoxide blood levels in man. Journal of Pharmaceutical Sciences, 56, 912.

WALES, J.K. \& WolfF, F. (1967) Haematological side effects of diazoxide. Lancet, i, 53.

\title{
Cytomegalovirus mononucleosis with urticaria
}

\author{
DAPHNE M. HUMPHREYS \\ M.B., M.R.C.P.* \\ Allan Myers \\ M.B., M.R.C.P. \\ * Royal Berkshire Hospital, Reading and The Royal Free Hospital, London
}

\begin{abstract}
Summary
A case of cytomegalovirus mononucleosis presenting with urticaria is described and so far as the authors know it is the first record of such an occurrence.

\section{Case history}

A 25-year-old woman presented on 19 October 1972, complaining of skin lesions for 5 days. Six days before admission to hospital she had developed lower retrosternal pain on swallowing, and the following day two patches of non-pruritic, nonpainful erythema appeared on the right thigh and later on the arms, fingers and face, and the lips became swollen. Chlorpheniramine $4 \mathrm{mg}$ t.i.d. lessened the swelling but had no effect on the other lesions. During the next 2 days the patches spread over the
\end{abstract}

legs and abdomen, and became painful and slightly itchy. Other symptoms included a sore throat for 3 days and central, colicky, abdominal pain associated with diarrhoea for 1 day. The only therapy before the onset of the rash was soluble aspirin and Benylin expectorant, and there had been no contact with known allergens.

Systematic enquiry was negative apart from symptoms of abdominal migraine as a child. There was nothing of significance in the family history.

\section{On examination}

The patient was a well nourished 25-year-old female with a temperature of $38.0^{\circ} \mathrm{C}$. The only abnormal findings were raised hot skin lesions over the arms, trunk and legs which closely resembled 
urticaria. There were no mouth lesions and no joint involvement. She was seen at this time by the consultant dermatologist who confirmed the diagnosis of urticaria, although at the time the diagnosis of erythema marginatum was raised, but this was unlikely as there were no other signs of rheumatic fever. There were no target lesions of the type associated with erythema multiforme.

\section{Initial investigations}

Haemoglobin $15 \mathrm{~g}$, red cell count $4.9 \mathrm{~m} / \mathrm{mm}^{3}$, white cell count $11,500 / \mathrm{mm}^{3}$ with a neutrophil leucocytosis, ESR $14 \mathrm{~mm}$; serum proteins: total 6.8 $\mathrm{g}$, albumin $3.5 \mathrm{~g}$; electrophoresis normal; throat swab: no pathogens isolated; antistreptolysin titre less than 200.

The white cell count repeated 4 days after admission was $7600 / \mathrm{mm}^{3}$ with a normal differential. Viral studies were done at the time of admission but the results were not then available.

\section{Treatment and progress}

Initially, therapy with chlorpheniramine $8 \mathrm{mg}$ t.i.d. produced no beneficial effect and the fever and skin lesions were still present 6 days later. Synacthen (tetracosactrin zinc phosphate) $1 \mathrm{mg}$ daily was therefore given and the skin lesions and pyrexia rapidly disappeared. The patient was subsequently discharged on Synacthen $1 \mathrm{mg}$ i.m. twice a week, with a diagnosis of urticaria of unknown aetiology. The pyrexia noted initially resolved after therapy with Synacthen and did not return.

The patient was readmitted 1 week later as her malaise had increased and it had been necessary to increase the dose of Synacthen to $1 \mathrm{mg}$ on alternate days. On admission there was no rash present and, following $24 \mathrm{hr}$ on water only by mouth, the skin lesions reappeared and in a few areas resembled erythema marginatum. After a further injection of $1 \mathrm{mg}$ of Synacthen the lesions again disappeared. Mebhydrolin (Fabahistin) $5 \mathrm{mg}$ and tripolidine (Pro-Actidil) $10 \mathrm{mg}$ nocte were given in addition to Synacthen $0.5 \mathrm{mg}$ twice weekly.

At this time the following investigations were carried out. The white cell count was $12,600 / \mathrm{mm}^{3}$ with atypical mononuclear cells and a neutrophil leucocytosis (differential white cell count: neutrophils $57 \%$, lymphocytes $36 \%$, monocytes $4 \%$ ); Paul Bunnell negative on three occasions; Rose Waaler titre $<16$; latex test negative; ESR $14 \mathrm{~mm}$; L.E. cells negative; immunofluorescent antibodies were positive for smooth muscle and kidney glomeruli; immunoglobulins, IgG 1400 (N400-1800) mg/100 $\mathrm{ml}$; IgA 430 (N90-450) mg/100 ml; IgM 400 (N40180) $\mathrm{mg} / 100 \mathrm{ml}$; serum proteins and electrophoresis normal.
She was discharged after 5 days, again with complete resolution of the rash with Synacthen, but in view of the repeated recurrence of the rash, increasingly frequent injections of Synacthen and a rise in the white cell count to $17,500 / \mathrm{mm}^{3}$ with atypical mononuclear cells not typically of glandular fever type, a bone marrow test was performed. This showed normal erythropoiesis with large numbers of atypical mononuclear cells. Immunoglobulins now showed a fall of IgM to $55 \mathrm{mg} / 100 \mathrm{ml}$, IgA was 70 $\mathrm{mg} / 100 \mathrm{ml}$, and $\mathrm{IgG}$ was $990 \mathrm{mg} / 100 \mathrm{ml}$. The virology results obtained at the time of this report were cytomegalovirus $1: 8$ first specimen (on admission) and 1 : 1024 second specimen (one month later). All other virus C.F. titres-influenza, para-influenza, adenovirus, psittacosis, Rickettsia, measles, respiratory syncytial virus, Mycoplasma pneumoniae, mumps, varicella-zoster, herpes simplex and leptospirosis were all $1: 8$, except for measles $(1 / 32)$ and influenza (1/16). Urine culture was negative for cytomegalic inclusion virus, and no inclusion bodies were present. A diagnosis of active infection with cytomegalovirus was made.

It was felt that withdrawal of Synacthen was advisable and this was done 2 months after admission in December. Following this, the patient continued to suffer from an extensive rash, particularly over the face, trunk and hands, which was severe on waking but gradually resolved throughout the day with minimal itching. The lesions on the knees and the feet and some extensive erythematous areas on the trunk were painful. By the latter part of January the urticaria was subsiding, and by the early part of February the rash had disappeared completely and the patient was symptom free and has remained well since.

Investigations in mid-February were: white cell count $7200 / \mathrm{mm}^{3}$; neutrophils $50 \%$; eosinophils $3 \%$; lymphocytes $39 \%$; monocytes $5 \%$; normal film; ESR $24 \mathrm{~mm}$; serum proteins normal. Immunoglobulins had reverted to normal, i.e. IgG 1250, IgA 400 , IgM $130 \mathrm{mg} / 100 \mathrm{ml}$. Complement fixation tests (CFTs) for cytomegalovirus throughout the illness were as follows: on admission to hospital $<1: 8$, one month after admission $1: 1024$, then 12 weeks after admission $1: 1024,20$ weeks after admission $1: 512,32$ weeks after admission $1: 512$, and 48 weeks after admission $1: 256$.

Urine for cytomegalovirus 15 January 1973 negative, 10 June 1973 positive, 22 October 1973 negative.

\section{Discussion}

The rapid high rise of antibodies in the CFTs for cytomegalovirus indicated active infection with this agent, and cytomegalovirus mononucleosis was diagnosed. 
From serological evidence, it seems that postnatally-acquired cytomegalovirus infection is very common. The older the age group, the higher the percentage of individuals with antibodies to cytomegalovirus as evidence of previous infection. Over the age of 50 years, $50 \%$ of the population have antibodies to the virus. Hitherto, cytomegalic inclusion disease due to acquired infection has been reported as a rare and serious illness that occurs primarily in individuals whose immune mechanisms have been depressed by some debilitating disease or by cytoxic drugs. Although most cytomegalovirus infections may not be apparent, there is good evidence that acquired cytomegalovirus infection not uncommonly produces a variety of clinical symptoms, especially in children, in whom the symptoms include hepatitis, hepato-splenomegaly and chronic liver disease, pertussis-like illnesses, bronchitis and pneumonia. Acquired cytomegalovirus infection sometimes presents as an acute febrile illness with the haematological features of infectious mononucleosis (but with a negative heterophil agglutination or Paul Bunnell Test) but tonsillitis or enlargement of the lymph nodes rarely occur. Involvement of the liver, sometimes with jaundice as a presenting sign, seems to be a regular feature of this disease which occurs in previously healthy individuals, particularly adults. Symptoms have occurred following transfusion with fresh blood. These findings have been reported by Klemola and Kaarianinen (1965) and Kaarianinen, Klemola and Paloheimo (1966) and again by Klemola et al. (1969) and subsequently confirmed by a number of authors. The name cytomegalovirus mononucleosis has been proposed for this type of cytomegalovirus manifestation. In all previously reported cases the only skin rashes were rubelliform in type, and occurred only in a minority of patients. As far as the authors can ascertain from the literature, no urticarial reaction of this type has hitherto been associated with cytomegalovirus inclusion mononucleosis.
The patient was started empirically on Synacthen as a diagnosis of urticaria of unknown aetiology was made by the consultant dermatologist. The titre against cytomegalovirus was $1: 8$ before Synacthen was given and 1 : 10241 month later, after Synacthen had been administered (total of seven injections i.m.). It is possible that the Synacthen may have precipitated an infection with cytomegalovirus in a patient with urticaria of unknown aetiology but then we would have to postulate the presence of two conditions. The subsidence of the urticaria occurred just before the titre to cytomegalovirus fell. It was $1: 10242$ weeks before the urticaria subsided completely and $1: 5126$ weeks afterwards. The only other drug the patient had before the appearance of the urticaria was aspirin and this has been reported as potentiating the development of an allergic response but the course of the disease in the patient would not incriminate this as a major factor. The fall of IgM and IgA at the height of the disease was presumably due to severe infection, particularly as they returned to normal 6 weeks after the urticaria subsided.

\section{Acknowledgment}

Our thanks are due to Dr E. V. Cox, M.D., F.R.C.P., for permission to publish this case, to Dr R. Emmerson, M.B., M.R.C.P., for his help and advice, and to members of the Pathology Department, Royal Berkshire Hospital, Reading.

\section{References}

KaArianinen, L., Klemola, E. \& Paloheimo, J. (1966) Rise of cytomegalovirus antibodies in an infectious mononucleosis-like syndrome after transfusion. British Medical Journal, i, 1270.

Klemola, E. \& KaARianinen, L. (1965) Cytomegalovirus as a possible cause of a disease resembling infective mononucleosis. British Medical Journal, ii, 1099.

Klemola, E., von Essen, R., Wager, O., Haltitia, K., Koivuniemi, A. \& SAlmi, I. (1969) Cytomegalovirus mononucleosis in previously healthy individuals. Four new cases and follow-up of 13 previously published cases. Annals of Internal Medicine 71. 11.

Weller, T.H. (1971) Cytomegaloviruses-ubiquitous agents with protean clinical manifestations. New England Journal of Medicine, 285, 203. 